\title{
Penilaian Kualitas Hidup pada Anak dengan Penyakit Jantung Bawaan Asianosis dan Sianosis
}

\author{
Cut Fera Rachmawati, Sri Sofyani, Muhammad Ali \\ Departemen Ilmu Kesehatan Anak Fakultas Kedokteran Universitas Sumatera Utara/ RS Haji Adam \\ Malik, Medan
}

Latar belakang. Setiap tahun seribu bayi lahir dengan penyakit jantung bawaan (PJB). Terapi bertujuan mengurangi gejala klinis, mencegah gagal jantung, penutupan defek, dan meningkatkan kualitas hidup. Evaluasi terhadap kualitas hidup menjadi penting karena dengan tata laksana yang baik sekarang ini, anak dengan PJB memiliki harapan hidup yang lebih lama.

Tujuan. Menilai perbedaan kualitas hidup anak penderita PJB asianosis dengan sianosis.

Metode. Penelitian menggunakan studi potong lintang telah dilakukan dari bulan Maret sampai dengan Juli 2012 di RSUP H. Adam Malik, Medan. Sampel terdiri dari anak usia 5 sampai dengan 18 tahun yang menderita PJB asianosis dan sianosis yang belum dikoreksi dan sudah dikoreksi. Anak dan orangtua mengisi kuesioner PedsQL modul kardio versi 3.0. Penilaian kualitas hidup dilihat dari enam domain yaitu menggunakan T-test independen dengan $\mathrm{p}<0,05$ dan interval kepercayaan $95 \%$.

Hasil. Terdapat 52 anak penderita PJB, 17 anak sianosis dan 37 anak asianosis. Kualitas hidup anak PJB asianosis lebih baik daripada anak sianosis dalam empat domain yaitu masalah jantung dan terapi, penampilan fisik, cemas terhadap tindakan terapi dan masalah kognitif.

Kesimpulan. Kualitas hidup anak penderita PJB asianosis lebih baik dibandingkan penderita PJB sianosis. Sari Pediatri 2014;16(2):86-90.

Kata kunci: penyakit jantung bawaan, kualitas hidup, PedsQL modul jantung

I

arapan hidup anak PJB (Penyakit Jantung Bawaan) meningkat seiring kemajuan di bidang pembedahan, $90 \%$ sampai dengan 95\% dapat bertahan hidup hingga

\footnotetext{
Alamat korespondensi:

Dr. Cut Fera Rachmawati. *Peserta Program Pendididikan Dokter Spesialis Anak Bagian Ilmu Kesehatan Anak FK USU/RS HAM Jalan Bunga Lau No 17 Medan - 20136 Telp. (061) 8361721, Fax.: (061) 8361721. E-mail : dr_cufey@yahoo.co.id
}

dewasa. ${ }^{1}$ Penyakit jantung bawaan dapat menjadi kondisi kronis karena beberapa faktor yang memengaruhi kehidupan pasien, meliputi lama penyakit, tanda dan gejala, berkurangnya tingkat aktivitas dan prognosis sehingga memengaruhi kualitas hidup pasien. ${ }^{2}$ Angka mortalitas secara signifikan turun dan akibat terapi PJB, menghasilkan populasi yang dapat bertahan hidup secara fisik, mental, dan psikososial. ${ }^{3}$

Keberhasilan suatu terapi tidak hanya diukur dari survival rate, tetapi juga dari kualitas hidup yang 
berhubungan dengan kesehatan. ${ }^{4}$ Penilaian kualitas hidup dapat digunakan untuk mengetahui prioritas masalah, media komunikasi, mendeteksi potensial masalah, mengidentifikasi, dan memonitor respons terhadap terapi. ${ }^{3}$ Penilaian kualitas hidup dapat dilakukan pada anak yang menderita penyakit kronis, seperti penyakit jantung, diabetes, obesitas, kelainan gastrointestinal, penyakit gagal ginjal, asma, rematik, kanker, gangguan psikiatri, cerebral palsy. ${ }^{5}$ Penilaian kualitas hidup menjadi penting pada anak dan remaja dengan PJB karena dapat memiliki harapan yang lebih baik, baik fisik, psikososial dan interaksi sosial sama dengan anak normal lainya. ${ }^{6}$

\section{Metode}

Penelitian ini adalah studi potong lintang. Data diperoleh dari anak dan orang tua penderita PJB asianosis dan sianosis yang berkunjung ke Poliklinik Kardiologi Anak FKUSU/RS. H. Adam Malik, Medan pada bulan Maret sampai Juli 2012. Kriteria inklusi adalah anak usia 5-18 tahun yang menderita semua jenis PJB asianosis dan sianosis yang sudah mendapat terapi lebih dari 4 bulan.

Seluruh subyek penelitian dan orang tua mengisi kuesioner PedsQL modul jantung versi 3.0 yang merupakan instrumen penilaian yang dipakai dalam penelitian ini, terdiri atas 6 skala masalah jantung dan terapi ( 7 pertanyaan), terapi II (5 pertanyaan), penampilan fisik (3 pertanyaan), cemas terhadap tindakan terapi (3 pertanyaan), masalah kognitif (5 pertanyaan), komunikasi (3 pertanyaan). Enam tingkatan tersebut dinilai dengan menggunakan angka nol (0) yang berarti tidak menjadi masalah sampai dengan empat (4) yang berarti hampir selalu menjadi masalah. Angka nol (0) sampai dengan empat (4) itu akan diinterpretasikan menjadi nilai nol (0) sampai 100 dengan perincian $0=100,1=75,2=50,3=25$ dan $4=0$, yang selanjutnya nilai tersebut akan dijumlahkan dan diambil nilai rata-ratanya. Nilai yang lebih tinggi menunjukkan kualitas hidup yang lebih baik

\section{Hasil}

Terdapat 54 anak penderita PJB yang memenuhi kriteria inklusi, terdiri atas 17 anak PJB sianosis dan 37 asianosis (Tabel 1). Pada PJB sianosis, diagnosis terbanyak adalah post operasi BT shunt atas indikasi TOF (38\%), dan diagnosis terbanyak pada PJB asianosis adalah defek septum ventrikel (38\%).

Hasil penilaian dari 6 domain berdasarkan laporan

Tabel 1. Karakteristik demografi sampel penelitian

\begin{tabular}{lcc}
\hline Karakteristik & Sianosis $\mathrm{n}=17$ & Asianosis $\mathrm{n}=37$ \\
\hline Usia (tahun), rerata SD & & \\
$5-7$ & $8(47)$ & $17(46)$ \\
$8-12$ & $4(23)$ & $15(41)$ \\
13-18 & $5(30)$ & $5(13)$ \\
Jenis kelamin, n (\%) & & \\
$\quad$ Laki-laki & $12(71)$ & $21(57)$ \\
$\quad$ Perempuan & $5(29)$ & $16(43)$ \\
Status gizi, n (\%) & & \\
$\quad$ Baik & $2(12)$ & $6(16)$ \\
Kurang & $15(88)$ & $31(84)$ \\
Pendidikan orangtua, n (\%) & & \\
Perguruan tinggi & $1(6)$ & $4(11)$ \\
SMA & $15(88)$ & $1(36)$ \\
SMP & $1(6)$ & $32(82)$ \\
Pekerjaan orangtua, n (\%) & & $4(10)$ \\
Wiraswasta & $16(94)$ & $1(8)$ \\
PNS & 0 & \\
Pekerja swasta & $1(6)$ & \\
\hline
\end{tabular}


anak dan orang tua menunjukkan perbedaan antara PJB asianosis dan sianosis pada kualitas hidup yang bermakna pada domain masalah jantung dan terapi, cemas terhadap tindakan terapi dan masalah kognitif (tabel 2) tua yang berlebihan sehingga mereka terlalu menjaga anaknya. ${ }^{9}$ Pada orang tua, stres berhubungan dengan harapan agar anaknya bisa hidup normal seperti anak lainnya. ${ }^{10,11}$ Tingkat pendidikan orang tua rata-rata SMA. Hal tersebut berhubungan dengan tingkat

Tabel 2. Perbedaan kualitas hidup kelompok PJB sianosis dengan asianosis

\begin{tabular}{lccc}
\hline Domain & Sianosis $(\mathrm{n}=17)$ rerata $(\mathrm{SD})$ & Asianosis $(\mathrm{n}=37)$ rerata $(\mathrm{SD})$ & $\mathrm{p}$ \\
\hline Laporan anak & & & \\
Masalah jantung dan terapi & $50,8 \pm 7,70$ & $71,3 \pm 11,53$ & 0,029 \\
Terapi II & $89,2 \pm 3,67$ & $92,5 \pm 5,28$ & 0,208 \\
Penampilan fisik & $69,0 \pm 18,48$ & $89,0 \pm 6,76$ & 0,030 \\
Cemas terhadap tindakan terapi & $60,5 \pm 9,11$ & $83,7 \pm 14,35$ & 0,000 \\
Masalah kognitif & $56,66 \pm 11,69$ & $80,0 \pm 5,42$ & 0,001 \\
Komunikasi & $86,0 \pm 5,58$ & $88,3 \pm 3,88$ & 0,706 \\
Laporan orangtua & & & \\
Masalah jantung dan terapi & $53,3 \pm 9,26$ & $71,4 \pm 7,75$ & 0,007 \\
Terapi II & $89,8 \pm 6,33$ & $89,2 \pm 5,28$ & 0,674 \\
Penampilan fisik & $67,5 \pm 20,57$ & $90,2 \pm 4,89$ & 0,033 \\
Cemas terhadap tindakan terapi & $57,3 \pm 11,34$ & $83,6 \pm 14,28$ & 0,000 \\
Masalah kognitif & $53,3 \pm 5,16$ & $78,3 \pm 4,85$ & 0,001 \\
Komunikasi & $87,6 \pm 4,13$ & $88,3 \pm 3,94$ & 0,363 \\
\hline
\end{tabular}

\section{Pembahasan}

Penyakit jantung bawaan dapat menjadi penyakit kronis dan memengaruhi kualitas hidup pasien. ${ }^{2}$ Pada penelitian ini, Kualitas hidup anak yang menderita PJB asianosis dan sianosis yang belum dikoreksi dan sudah dikoreksi dinilai. Hasil penilaian dari 6 domain berdasarkan laporan anak dan orang tua menunjukkan perbedaan pada domain masalah jantung dan terapi, masalah kognitif, penampilan fisik serta cemas terhadap tindakan terapi.

Anak dengan PJB sianosis lebih berisiko terjadinya gangguan serebral, khususnya pada saat terjadi spells (sianosis) atau meningkatnya viskositas darah karena terjadi hipoksemia, sianosis, polisitemia dan mikrositosis yang dapat memengaruhi fungsi kognitif. ${ }^{7}$ Masalah fungsi kognitif dijumpai pada penelitian ini berdasarkan laporan anak dan orang tua. Penelitian di Norwegia, pada anak usia 7-12 tahun, ditunjukkan bahwa anak dengan PJB yang telah menjalani operasi Cardiopulmonary bypass (CPB) mengalami masalah kualitas hidup. ${ }^{8}$

Gangguan fungsi kognitif pada lesi sianosis tidak hanya akibat dari hipoksia kronis, tetapi akibat faktor lain yang memengaruhi, seperti kekhawatiran orang kecemasan yang lebih tinggi dibandingkan dengan orang tua yang berpendidikan perguruan tinggi sehingga diperlukan penjelasan yang detail tentang penyakit PJB pada anaknya.

Hasil penelitian ini juga menunjukkan bahwa nilai kualitas hidup dari orang tua pada domain masalah kognitif lebih rendah daripada nilai laporan anak karena tingkat kecemasan orang tua lebih tinggi. Didapatkan bahwa domain masalah kognitif pada anak lesi asianosis tidak menunjukkan masalah. Anak dengan PJB sianosis mengalami kesukaran berinteraksi dengan lingkungan akibat kondisi penyakitnya, ibu yang terlalu melindungi sehingga interaksi sosial anak terbatas, lama dan rawatan ulangan di rumah sakit juga dapat memengaruhi fungsi kognitif anak. Berbeda pada PJB sianosis, penilaian domain masalah kognitif anak dengan lesi asianosis tidak menunjukkan masalah.

Penelitian metaanalisis pada anak dan remaja dijumpai fungsi kognitif yang lebih rendah pada kelompok PJB sianosis daripada asianosis. ${ }^{12}$ Penelitian di Amerika pada anak usia 3,5--17 tahun kelompok PJB sianosis dan asianosis ditunjukkan bahwa pada kelompok TOF yang mengalami hipoksemia (sianosis) terdapat gangguan pemusatan perhatian dibandingkan dengan defek septum ventikel yang tidak mengalami 
Cut Fera Rachmawati dkk: Penilaian kualitas hidup dengan penyakit jantung bawaan asianosis dan sianosis

hipoksemia (sianosis). ${ }^{13}$ Sebuah sistematic review pada anak kelompok usia 1-3, 3-5, dan 5-17 tahun ditunjukkan bahwa anak dengan lesi asianosis memiliki perkembangan fungsi kognitif yang lebih baik. ${ }^{14}$

Beberapa faktor yang memengaruhi kualitas hidup anak dengan PJB, antara lain tingkat kecemasan orang tua, tingkat pendidikan orang tua, depresi pada orang tua, perubahan pandangan anak terhadap tubuhnya setelah operasi (ada atau tidak adanya luka bekas operasi), kurangnya penerimaan dari lingkungan sosial dan sekolah serta aktivitas fisik yang berkurang. ${ }^{15}$ Pada bayi dan anak PJB, tindakan pembedahan dapat meningkatkan kualitas hidup. ${ }^{16,17}$ Hasil penelitian ini menunjukkan bahwa domain masalah jantung dan terapi pada semua kelompok usia asianosis dan sianosis berdasarkan laporan anak dan orang tua menunjukkan nilai kualitas hidup yang lebih baik pada PJB yang sudah dikoreksi karena anak sudah dapat melakukan aktivitas fisik yang lebih baik seperti berolah raga, denyut jantung berdetak kencang tidak dirasakan lagi dan tidak dijumpai lagi bibir biru pada PJB sianosis. Nilai domain masalah kognitif pada PJB sianosis dan asianosis yang sudah dikoreksi menunjukkan nilai yang lebih baik daripada yang belum dikoreksi. Hal tersebut bisa disebabkan karena anak telah dapat menjalani kehidupan seperti anak normal lainnya.

Penelitian kohort prospektif pada anak usia 8 tahun yang telah menjalani operasi PJB, ditunjukkan bahwa nilai intelligence quotient (IQ) mereka mendekati nilai IQ anak normal lainnya. ${ }^{18} \mathrm{Kami}$ mendapatkan kualitas hidup yang lebih baik pada PJB asianosis dibandingkan dengan PJB sianosis.

Anak dengan lesi asianosis menunjukkan prognosis yang lebih baik. ${ }^{19}$ Penelitian ini menunjukkan hasil kualitas hidup pada kedua kelompok PJB lebih baik setelah dilakukan tindakan koreksi.

\section{Kesimpulan}

Anak penderita PJB asianosis memiliki kualitas hidup yang lebih baik dibandingkan dengan anak sianosis. Laporan anak dan orang tua menunjukkan kualitas hidup yang lebih baik pada domain masalah jantung dan terapi, penampilan fisik, cemas terhadap tindakan terapi dan masalah kognitif daripada anak penderita PJB sianosis berdasarkan laporan anak dan orang tua.

\section{Daftar pustaka}

1. Uzark K, Jones K, Slusher J, Limbers AC, Burwinkle MT, Varni WJ. Quality of life in children with heart disease as perceived by children and parents. Pediatrics 2008; $121: 1060-7$.

2. Moons P, Norekval MT. Is sense of coherence a pathway for improving the quality of life of patients who grow up with chronic diseases? A hipothesis. Eur J Cardiovacs Nurs 2006;5:16-20.

3. Marino SB, Tomlinson SR, Welkom SJ, Helfaer AM, Wernovsky G, Shea AJ. Quality of life concern differ among patients, parents and medical providers in children and adolescents with congenital and acquired heart disease. Pediatrics 2009;123:708-14.

4. Sitaresmi MN. Penilaian kualitas hidup yang berhubungan dengan kesehatan (health related quality of life). Dalam: Lubis B, Ali M, Yanni GN, dkk, penyunting. Kumpulan Naskah Lengkap PIT IV IKA Medan; 22-24 Februari 2010; Medan, Indonesia. Medan: USU press; 2010.h.109-14.

5. Varni JW, Limbers AC, Burwinkle MT. Impaired health related quality of life in children and adolescents with cronic conditions: a comparative analysis of 10 disease clusters and 33 disease categories/severities utilizing the PedsQL ${ }^{\text {TM }} 4.0$ generic core scales. Biomed 2007;5:115

6. Marino SB, Tomlinson SR, Welkom SJ, Helfaer AM, Wernovsky G, Shea AJ. Quality of life concern differ among patients, parents and medical providers in children and adolescents with congenital and acquired heart disease. Pediatrics 2009;123:708-14.

7. Moons P, Deyk VK, Budts W, Geest DS. Caliber of quality of life assessments in congenital heart disease. Arch Pediatr Adolesc Med 2004;158:1062-9.

8. Latal B, Helfricht S, Fischer EJ, Bauersfeld U, Landolt AM. Psychological adjustment and quality of life in children and adolescents following open-heart surgery for congenital heart disease: a systematic review. BMC Pediatr 2009;9:1-10.

9. Shillingford JA, Glanzman MM, Ittenbach FR, Clancy RR, Gaynor WJ, Wernovsky G. Inattention, hyperactivity and school performance in a population of school-age children with complex congenital heart disease. Pediatrics 2008;121:759-65.

10. Nousi D, Christou A. Factors affecting the quality of life in children with congenital heart disease. Health Sci J 2010;4:94-9.

11. Davis CC, Brown RT, Bakeman R, Campbell R. 
Psychological adaptation and adjustment of mothers of children with congenital heart disease: stress, coping and family functioning. J Pediatr Psychol 1998;23:219-28.

12. Wray J. Sensky T. Controlled study of preschool development after surgery for congenital heart disease. Arch Dis Child.2009;80:511-16.

13. Shillingford JA, Glanzman MM, Ittenbach FR, Clancy RR, Gaynor WJ, Wernovsky G. Inattention, hyperactivity and school performance in a population of school-age children with complex congenital heart disease. Pediatrics 2008;121:759-65.

14. Snookes SH, Gunn JK, Eldridge BJ, Donath SM, Hunt RW, Galea MP, dkk. A systematic review of motor and cognitive outcomes after early surgery for congenital heart disease. Pediatrics 2010;125:818-24.

15. Nousi D, Christou A. Factors affecting the quality of life in children with congenital heart disease. Health Sci J.2010;4:94-9.

16. King III SB, Nash IS, Robert R. Incidence and etiology. Dalam: Fuster V, Waish RA, O’Rourke RS, Wilson PP, penyunting. The heart. Edisi ke-12. Philadelphia: Mc Graw - Hill's;2008. h.1-68.

17. Forbess MJ, Visconti JK, Friesen CH, Howe RC, Bellinger DC, Jonas RA. Neurodevelopmental outcomes after congenital heart surgery: results from an institutional registry. Circulation 2002;106:95-9.

18. Schultz AH, Wernovsky G. Late outcomes in patients with surgically treated congenital heart disease. Pediatr Card Surg Ann 2005;8:145-56.

19. Wray J, Sensky T. Congenital heart disease and cardiac surgery in childhood:effects on cognitive function and academic ability. Heart 2001; 85:687-91. 